\title{
Correlates of mistime pregnancy and unmet need for family planning among women of reproductive age in Sandema, Ghana.
}

Elvis Junior Dun-Dery ( $\nabla$ dunderyejunior@yahoo.co.uk)

University of Ghana https://orcid.org/0000-0002-5551-5031

Elijah Yendaw

University for Development Studies

Frederick Dun-Dery

Heidelberg Institute of Global Health, Medical Faculty, Ruprecht-Karls Universität, Germany

Lawrence Bagrmwin

University for Development Studies

\section{Research}

Keywords: Family planning, unmet need, mistime pregnancy, Sandema, contraceptives

Posted Date: December 20th, 2019

DOI: https://doi.org/10.21203/rs.2.19493/v1

License: (a) (i) This work is licensed under a Creative Commons Attribution 4.0 International License.

Read Full License 


\section{Abstract}

Background: Universally, an estimated 80 million unintended pregnancies comprising both mistimed and unwanted pregnancies are recorded yearly, but only half of women at risk of a mistimed pregnancy use contraceptives. In developing countries, over 100 million females have unmet need and national surveys in Ghana indicate a $29 \%$ unmet need rate.

Methods: A cross-sectional community based study was used, involving the use of multi-step cluster sampling methods in selecting 300 women of reproductive age. The study was quantitative in nature, using structured interviewer administered questionnaires.

Results: More than half (66\%) of the women in reproductive age still had unmet need, $71 \%$ were currently pregnant and $36 \%$ confirmed ever having a mistimed pregnancy. Overall, $53 \%$ of the women confirmed never communicating on family planning issues with their partners, a little below half (45\%) of the respondents took their own health care decisions and $79 \%$ ever received family planning services from a health professional. Factors related to unmet need included mistimed pregnancy, level of education, preferred birth/pregnancy interval, communication between partners and the autonomy to spend selfearnings.

Conclusion: Considering that high rates of unmet need results in mistimed pregnancy, improved policies around the influence of unmet need on mistimed pregnancies are needed.

\section{Background}

The problem of unintended pregnancy is crucial to demographers in quest to understand fertility and to promote woman's ability to determine when to have children (Adhikari, Soonthorndhada, \& Prasartkul, 2009). Globally, an estimated 80 million unintended pregnancies, both mistimed and unwanted, occur each year (Tebekaw, Aemro, \& Teller, 2014). Arega and colleagues (2016), defined unintended pregnancy as a mistimed, unplanned or unwanted pregnancy at the time of conception. Each year, in the developing world, only about half of the women at risk of experiencing mistimed pregnancy use a method of contraception (Fotso, Izugbara, Saliku, \& Ochako, 2014). This leads to over 100 million female having unmet need in developing countries (Relwani et al., 2015). Unmet need is termed as the discrepancy between a woman's reproductive intentions and her birth control practices (Akanksha, Nandkeshav, Kalpana, Vijay, \& Mohan, 2014; Letamo \& Navaneetham, 2015). Many women continue to have unmet need for FP as a result of various factors (Wulifan, Brenner, Jahn, \& Allegri, 2016). In addition, married women of reproductive age group have unmet need for contraception, inability to use family planning methods to prevent or limit pregnancy despite the interest of practicing it (Mekonnen \& Worku, 2011). The situation has existed in the last decade, with contraception prevalence being stagnant and the increase of unmet need occurring (Ayuningtyas, 2016). Previous studies in Pakistan revealed fear of side effects, spousal communication, cultural and social acceptance as the decisive obstacles to decreasing unmet need among women of reproductive age (Hameed, Azmat, Bilgrami, \& Ishaqe, 2011). 
In Ghana, national surveys observed that a large number of women have an unmet need for family planning, as the acceptor rate for family planning services remains low (Paschal \& Matthew, 2015). The Ghana Demographic Health Survey reports thirty percent of currently married women have an unmet need for family planning, with 17 percent having an unmet need for spacing and 13 percent having an unmet need for limiting (GSS et al., 2015). The situation of unmet need is of important concern in Ghana and yet very few studies have been undertaken on the correlates of mistimed pregnancies and unmet need for family planning (Eliason, Baiden, Yankey, \& Asare, 2014), and there is a dearth of information on the relationship between unmet need and mistimed pregnancy. The objective of this study was to establish the relationship between unmet need and mistimed pregnancy in Ghana.

\section{Methodology}

Study design area, population, and inclusion criteria

A cross sectional community based study was conducted targeting women of child-bearing age (15 years to 45 years) in Sandema in the Builsa North District of the Upper East Region of Ghana. The study involved only quantitative data collection methods and excluded women who were not within child bearing age. The selection of participants involved a multi-step sampling technique. For the purpose of this study, women with an unmet need for family planning were defined as those who have had a recent delivery, thus presumed to be fecund, and report not wanting any more children at all or wanting to delay the birth of their next child; but not using any method of contraception (Pasha et al., 2015). The data were collected using a pretested and validated questionnaire and analysed using the Statistical Package for Social Sciences (SPSS version 20).

Sampling technique and Sample size determination

A cross-sectional survey was used and the study considered women with child bearing age as the sampling unit. Sandema is the district capital of the Builsa North District and the study used a systematic sampling technique in sampling 314 out of 4,941 houses. The total number of houses in the district $(4,941)$ was divided by the estimated sample size (314) and a random number (3) was generated between 1 and 15 as a starting point. At the household level, simple random sampling was used in selecting respondents. Women were made to select pieces of papers on which "yes" and "no" were written. Any woman who selected yes, was invited and interviewed until the sample size was reached. Sample size was calculated considering the 2015 unmet need rate of the region (26.5\%), a confidence interval of $95 \%$ and threshold of error at $5 \%$. The sample size for this study was calculated as follows:

$\mathrm{n}=\left(\mathrm{Z}^{2} \times \mathrm{PQ}\right) / \mathrm{d} 2$, where $\mathrm{n}$ represents the desired sample size, $\mathrm{Z}$ is the normal standard deviate, whose value at $95.0 \%$ confidence level is $1.96, P=$ current unmet need rate; $26.5 \%(0.265)$ (GSS et al., 2015), $Q=$ $1-P=0.7$, and $d=$ the set margin of error; 0.05 . Thus minimum sample size, $n=299.6$ or $n=300$. The figure was upwardly adjusted by $5 \%$ to cater for possible non-respondents or recording errors. Resultant sample size was 314 . 
For the purpose of this study, a woman was considered to have an unmet need if she was pregnant or at the post-partum stage but reported that her pregnancy was not wanted at that time or she was fecund but wanted to stop child birth or delay the next pregnancy but was not using any contraceptive methods. Again, respondents were asked if they wanted to be pregnant at the time of conception. If such women considered the pregnancy to have come at the wrong time, then she was considered to have an unmet need. Women who had hysterectomy, or attained menopause or self-reported fecundity were considered to be fecund. The study numerator did not include women who had successfully used natural family planning to prevent or delay pregnancy for the past five years or whose husbands were away for a considerable period but later wanted a child or women who had children less than six months of age.

Data collection

A structured questionnaire was developed and administered to participants. The consent forms and data collection instruments were interpreted to respondents in their preferred local language if they could not understand the English language. Prior to the data collection, supervisors and data collectors were given three days intensive training on the aim of the study, procedures and data collection techniques. Research assistants were also trained on ensuring participant's confidentiality and handling of non-responses. Once a woman was considered eligible, she was invited orally to participate in the study. All data collectors pre-tested the questionnaire on 50 respondents who were living in the Navirango central of the same region, which has similar demographic characteristics as Sandema district.

Data analysis

Data was entered into Statistical Package for Social Sciences for analysis and data cleaning was done prior to analysis. The analysis produced descriptive statistics on demographics and other factors that were assessed. Frequency and percentage tables were formed to give a better understanding of the results. Uni-variate logistic regressions were also performed to test associations between various variables, considering a significant $p<0.05$.

\section{Results}

Background attributes of respondents

Three hundred (300) respondents were sampled for this study. An overview of demographic characteristics indicates that majority of the respondents (37\%) were between the ages of 25 and 29 and the least group (ages $30-34$ ) was only $17 \%$ of the sampled population. In addition, $32 \%$ were senior high school graduates, $14 \%$ had completed tertiary education and $16 \%$ were uneducated. A little below half (47\%) were self-employed, $31 \%$ were unemployed and one in every three of them worked at both public and private sectors. Majority of them were Christians (86\%), $13 \%$ were Muslims, while four respondents (1\%) were African Traditional Religious believers. More than half $(71 \%)$ of the respondents were urban 
dwellers, while $29 \%$ were rural dwellers. More than half (66\%) of the women in reproductive age still had unmet need, $71 \%$ were currently pregnant and $36 \%$ confirmed ever having a mistimed pregnancy (Table 1). 
Table 1

Background attributes of respondents $(\mathrm{N}=300)$

\begin{tabular}{|c|c|c|}
\hline Attribute & Frequency & Percentage (\%) \\
\hline \multicolumn{3}{|l|}{ Age of respondent (in years) } \\
\hline $15-24$ & 69 & 23.0 \\
\hline $25-29$ & 110 & 36.7 \\
\hline $30-34$ & 51 & 17.0 \\
\hline $35-49$ & 70 & 23.3 \\
\hline \multicolumn{3}{|l|}{ Level of education } \\
\hline Not educated & 48 & 16.0 \\
\hline Primary & 40 & 13.3 \\
\hline Junior High School/Technical & 74 & 24.7 \\
\hline Senior High School & 95 & 31.7 \\
\hline Tertiary & 43 & 14.3 \\
\hline \multicolumn{3}{|l|}{ Type of employment } \\
\hline Public servant & 27 & 9.0 \\
\hline Private servant & 39 & 13.0 \\
\hline Self-employed & 142 & 47.3 \\
\hline Unemployed & 92 & 30.7 \\
\hline \multicolumn{3}{|l|}{ Religious affiliation } \\
\hline Christian & 257 & 85.7 \\
\hline Muslim & 39 & 13.0 \\
\hline Traditionalist & 4 & 1.3 \\
\hline \multicolumn{3}{|l|}{ Place of settlement } \\
\hline Rural & 87 & 29.0 \\
\hline Urban & 213 & 71.0 \\
\hline \multicolumn{3}{|l|}{ Currently pregnant } \\
\hline Yes & 213 & 71.0 \\
\hline No & 87 & 29.0 \\
\hline
\end{tabular}




\begin{tabular}{|lll|}
\hline Attribute & Frequency & Percentage (\%) \\
\hline Ever had a mistimed pregnancy & & \\
\hline Yes & 107 & 35.7 \\
\hline No & 193 & 64.3 \\
\hline Have unmet need & 197 & 65.7 \\
Yes & 103 & 34.3 \\
No & & \\
Received FP from a health professional & 236 & 78.7 \\
Yes & 64 & 21.3 \\
No & & \\
\hline Preferred birth interval & 108 & 36.0 \\
6 months to1 year & 72 & 24.0 \\
1 year to 6 months & 92 & 30.7 \\
18 months to 2 years & 20 & 6.7 \\
2 years to 6 months & 8 & 2.6 \\
More than 30 months & & \\
\hline
\end{tabular}

Spousal autonomy and communication on family planning

Overall, more than half $(53 \%)$ of the women confirmed never communicating on family planning issues with their partners while $47 \%$ had discussed family planning matters with their partners. Among those who ever engaged in discussions related to family planning, majority (51\%) confirmed initiating the communication, but $49 \%$ said their partners initiated the communication. Less than half $(43 \%)$ of respondents' partners approved the use of family planning (FP) against $57 \%$ who never gave an approval for the use of family planning. Spousal autonomy was also discussed: less than half of the respondents $(49 \%)$ had the authority to decide how to spend their personal earnings. Twenty-six per cent $(26 \%)$ of respondents said the spending decisions of their earnings were decided by their partners. However, collective spending decisions were taken by $21 \%$ of respondents. On decisions relating to health care, less than half $(45 \%)$ of the respondents took their own health care decisions; $32 \%$ of the respondents said their spouse/partners took health care decisions on their behalf while $22 \%$ jointly took health care decisions. In all, a little over eight out of every ten (81\%) respondents had a positive perception towards contraceptives (Table 2) 
Table 2

Spousal autonomy and communication on family planning

\begin{tabular}{|lll|}
\hline Attribute & Frequency & Percentage (\%) \\
\hline $\begin{array}{l}\text { Partners communicate on FP } \\
\text { Yes }\end{array}$ & 141 & 47.0 \\
No & 159 & 53.0 \\
\hline Person who starts communication $(\mathrm{n}=213)$ & & \\
\hline Respondent & 109 & 51.2 \\
\hline Spouse/partner & 104 & 48.8 \\
\hline Approval of FP use by partner $(\mathrm{n}=213)$ & & \\
\hline Yes & 92 & 43.2 \\
\hline No & 121 & 56.8 \\
\hline Autonomy on personal earning & & \\
\hline Respondent decides & 148 & 49.3 \\
\hline Spouse/partner decides & 87 & 29.0 \\
\hline Respondent and spouse/partner jointly & 65 & 21.7 \\
\hline Autonomy on personal health care & & \\
\hline Respondent & 136 & 45.3 \\
\hline Spouse/partner & 97 & 32.3 \\
\hline Respondent and spouse/partner jointly & 67 & 22.4 \\
\hline $\begin{array}{l}\text { Perception towards contraceptives } \\
\text { Positive perception }\end{array}$ & 243 & 81.0 \\
\hline Negative perception & 57 & 19.0 \\
\hline
\end{tabular}

Associations between background characteristics and unmet need (Bi-variate analysis)

In testing the associations between respondents' characteristics and unmet need, the results indicate that respondents' level of education ( $p<0.030)$, ever having a mistimed pregnancy $(p<0.033)$ and desired pregnancy/birth interval $(p<0.022)$ were all statistically significant and related to respondents' unmet need. Aside this, all other background characteristics did not have any statistical relationship with unmet need (Table 3). 
Table 3

Associations between background characteristics and unmet need (Bi-variate analysis)

\begin{tabular}{|c|c|c|c|}
\hline & Unmet need & & \\
\hline Attribute & Yes & No & $p$-value \\
\hline $\begin{array}{l}\text { Age of women (years) } \\
15-24 \\
25-29 \\
30-34 \\
35-49\end{array}$ & $\begin{array}{l}22(36.7) \\
36(30.3) \\
17(31.5) \\
22(32.8)\end{array}$ & $\begin{array}{l}38(63.3) \\
83(69.8) \\
37(68.5) \\
45(67.2)\end{array}$ & 0.278 \\
\hline $\begin{array}{l}\text { Level of education } \\
\text { No education } \\
\text { Primary } \\
\text { JHS/Technical } \\
\text { SHS } \\
\text { Tertiary }\end{array}$ & $\begin{array}{l}10(20.0) \\
15(40.5) \\
23(27.0) \\
40(44.4) \\
9(23.7)\end{array}$ & $\begin{array}{l}40(80.0) \\
22(59.5) \\
62(72.9) \\
50(55.6) \\
29(76.3)\end{array}$ & 0.030 \\
\hline $\begin{array}{l}\text { Type of employment } \\
\text { Public Worker } \\
\text { Private Worker } \\
\text { Self-employed } \\
\text { Unemployed }\end{array}$ & $\begin{array}{l}10(33.3) \\
14(38.9) \\
46(31.5) \\
27(30.7)\end{array}$ & $\begin{array}{l}20(66.7) \\
22(61.1) \\
100(68.5) \\
61(69.3)\end{array}$ & 0.291 \\
\hline $\begin{array}{l}\text { Religion affiliation } \\
\text { Christian } \\
\text { Muslim } \\
\text { Traditionalist }\end{array}$ & $\begin{array}{l}84(33.2) \\
13(29.6) \\
0(0.0)\end{array}$ & $\begin{array}{l}169(66.8) \\
31(70.5) \\
3(100.0)\end{array}$ & 0.411 \\
\hline $\begin{array}{l}\text { Place of settlement } \\
\text { Rural } \\
\text { Urban }\end{array}$ & $\begin{array}{l}31(27.7) \\
66(35.1)\end{array}$ & $\begin{array}{l}81(72.3) \\
122(64.9)\end{array}$ & 0.083 \\
\hline $\begin{array}{l}\text { Currently pregnant } \\
\text { Yes } \\
\text { No }\end{array}$ & $\begin{array}{l}8(28.6) \\
20(44.9)\end{array}$ & $\begin{array}{l}105(71.4) \\
80(55.1)\end{array}$ & 0.508 \\
\hline \multicolumn{4}{|l|}{ Ever had a mistimed pregnancy } \\
\hline $\begin{array}{l}\text { Yes } \\
\text { No }\end{array}$ & $\begin{array}{l}58(41.1) \\
45(39.1)\end{array}$ & $\begin{array}{l}84(58.9) \\
113(60.9)\end{array}$ & 0.033 \\
\hline $\begin{array}{l}\text { Received FP from a health professional } \\
\text { Yes } \\
\text { No }\end{array}$ & $\begin{array}{l}31(27.7) \\
66(35.1)\end{array}$ & $\begin{array}{l}81(72.3) \\
122(64.9)\end{array}$ & 0.581 \\
\hline $\begin{array}{l}\text { Preferred birth interval } \\
6 \text { months to } 1 \text { year } \\
1 \text { year and } 6 \text { months } \\
18 \text { months to } 2 \text { years } \\
2 \text { years and } 6 \text { months } \\
\text { More than } 30 \text { months }\end{array}$ & $\begin{array}{l}19(65.5) \\
37(52.9) \\
20(33.3) \\
12(29.3) \\
4(21.1)\end{array}$ & $\begin{array}{l}10(34.5) \\
33(47.1) \\
40(66.7) \\
29(70.7) \\
15(78.9)\end{array}$ & 0.022 \\
\hline
\end{tabular}


Associations between spousal autonomy, communication on FP and unmet need (Bi-variate analysis).

In relating spousal autonomy, FP communication and unmet need, spousal discussion of FP $(\mathrm{p}<0.002)$ and autonomy on how to spend personal earning $(p<0.035)$ were the only significant variables noted. However, initiator of FP discussion, decision making on health care, decision making on spending earnings, and all other variables were not significant (Table 4).

Table 4

Associations between spousal autonomy, communication on FP and unmet need (Bi-variate analysis)

\begin{tabular}{|c|c|c|c|}
\hline \multicolumn{4}{|c|}{ Unmet need } \\
\hline Attributes & Yes & No & $\mathrm{p}$-value \\
\hline $\begin{array}{l}\text { Partners communicate on FP } \\
\text { Yes } \\
\text { No }\end{array}$ & $\begin{array}{l}55(40.4) \\
42(25.6)\end{array}$ & $81(59.6) 122(74.4)$ & 0.002 \\
\hline $\begin{array}{l}\text { Person who starts communication } \\
\text { Respondent } \\
\text { Spouse/partner }\end{array}$ & $\begin{array}{l}37(41.1) \\
18(39.1)\end{array}$ & $\begin{array}{l}53(58.9) \\
28(60.9)\end{array}$ & 0.349 \\
\hline $\begin{array}{l}\text { Autonomy on personal earnings } \\
\text { Respondent decides } \\
\text { Spouse/partner decides } \\
\text { Respondent and spouse/partner jointly }\end{array}$ & $\begin{array}{l}55(36.7) \\
29(37.2) \\
13(19.1)\end{array}$ & $\begin{array}{l}95(63.3) \\
49(62.8) \\
55(80.9)\end{array}$ & 0.019 \\
\hline $\begin{array}{l}\text { Autonomy on personal health care } \\
\text { Respondent } \\
\text { Spouse/partner } \\
\text { Respondent and spouse/partner jointly }\end{array}$ & $\begin{array}{l}43(31.6) \\
39(42.9) \\
14(20.0)\end{array}$ & $\begin{array}{l}93(68.4) \\
52(57.1) \\
56(80.0)\end{array}$ & 0.035 \\
\hline $\begin{array}{l}\text { Perception towards contraceptives } \\
\text { Positive perception } \\
\text { Negative perception }\end{array}$ & $\begin{array}{l}18(39.1) \\
37(41.1)\end{array}$ & $\begin{array}{l}28(60.9) \\
53(58.9)\end{array}$ & 0.086 \\
\hline
\end{tabular}

Predictors of Unmet Need

The study also built a multiple logistic regression model to test for the significance and direction of the relationship between dependent and independent variables. The model considered all variables that were significant at $p<0.05$ at the simple logistic regression level. The results indicate that as compared to respondents who had no educational attainment, respondents with primary (AOR 1.32, 95\%Cl: 0.65-3.28, secondary (AOR 1.50, Cl: 1.54-3.13) or tertiary level of education (AOR 1.58, Cl: $0.12-1.81$ ), were all more likely to have an unmet need. However, only Junior High or Technical education was a significant determinant of unmet need (AOR 1.50, 95\%Cl: 1.54-3.13). On the issue of preferred birth interval, women who preferred to delay their next pregnancy for a period of between 6 months and 1 year (AOR 0.27, Cl: 0.39-2.82), 18 months to 2 years (AOR 0.30, Cl: 0.12-0.59), 2 years and 6 months (AOR 0.11, Cl: $0.61-$ 0.98 ), and more than 30 months (AOR $0.84, \mathrm{Cl}$ : 0.24-0.42), were all less likely to have an unmet need. 
Respondents who did not have a mistimed pregnancy were also less likely to have an unmet need (OR 0.09 , Cl: 1.33-2.15) but mistimed pregnancy significantly determined unmet need among women.

Respondents who did not discuss family planning issues with spouse (AOR 0.19, Cl: 0.67-2.08), respondent's partner deciding on how respondent should spend her own earnings (AOR 0.51, Cl: 0.791.21), joint decision on how to spend respondent's earnings (AOR $0.28, \mathrm{Cl}: 0.58-1.18$ ) were all less likely to determine unmet need among women of reproductive age. Similarly, as compared to respondents who take decisions on their own health, those whose partners take decisions on behalf of respondents (AOR 2.27, Cl: 0.09-2.34), and joint partner decision on respondent's health (AOR 4.19, $\mathrm{Cl}$ : 1.82-3.11) were more likely to determine unmet need (Table 5).

\begin{tabular}{|c|c|}
\hline \multirow[t]{2}{*}{ Predictors } & Unmet need \\
\hline & AOR $(95 \% \mathrm{Cl})$ \\
\hline $\begin{array}{l}\text { Level of education } \\
\text { No education } \\
\text { Primary } \\
\text { JHS/Technical } \\
\text { SHS } \\
\text { Tertiary }\end{array}$ & $\begin{array}{l}\text { Ref } \\
1.320 .65-3.28 \\
1.501 .54-3.13 \\
1.330 .63-2.48 \\
1.580 .12-1.81\end{array}$ \\
\hline $\begin{array}{l}\text { Preferred birth interval } \\
1 \text { year } \\
1 \text { year and } 6 \text { months } \\
18 \text { months to } 2 \text { years } \\
2 \text { years and } 6 \text { months } \\
\text { More than } 30 \text { months }\end{array}$ & $\begin{array}{l}\text { Ref } \\
0.270 .39-2.82 \\
0.300 .12-0.59 \\
0.110 .61-0.98 \\
0.840 .24-0.42\end{array}$ \\
\hline $\begin{array}{l}\text { Ever had a mistimed pregnancy } \\
\text { Yes } \\
\text { No }\end{array}$ & $\begin{array}{l}\text { Ref. } \\
0.091 .33-2.15\end{array}$ \\
\hline $\begin{array}{l}\text { Partners communicate on FP } \\
\text { Yes } \\
\text { No }\end{array}$ & $\begin{array}{l}\text { Ref } \\
0.910 .67-2.08\end{array}$ \\
\hline $\begin{array}{l}\text { Autonomy on personal earnings } \\
\text { Respondent decides } \\
\text { Spouse or partner decides } \\
\text { Respondent and spouse/partner jointly }\end{array}$ & $\begin{array}{l}\text { Ref } \\
0.510 .79-1.21 \\
0.280 .58-1.18\end{array}$ \\
\hline $\begin{array}{l}\text { Autonomy on personal health care } \\
\text { Respondent decides } \\
\text { Spouse/partner decides } \\
\text { Respondent and spouse/partner jointly }\end{array}$ & $\begin{array}{l}\text { Ref. } \\
2.270 .09-2.34 \\
4.191 .82-3.11\end{array}$ \\
\hline 95\% Cl: 95\% confidence interval, AOR: A & d Odds Ratio \\
\hline
\end{tabular}

\section{Discussion}


The study indicates that although women and their partners had positive perception towards family planning (81\%), unmet need among women was still high (66\%). Elsewhere in Senegal, Hindin et al., (2015), also found as high as $70 \%$ of women with unmet need, as well as Chebet et al., (2015). Reasons such as limited access to family planning services, poor family planning education and counselling, perception about side effects associated with contraceptives could account for this shortfall in translating perception into practice. Meanwhile other regional surveys in Ghana recorded low unmet need, contrary to findings of this study (Eliason et al., 2014). Again, both this study and earlier studies have indicated the significance of education on the impact of unmet need and mistimed pregnancy (Ajong et al., 2016 ; Ibrahim \& Iwaoeye, 2012 ; Ajong et al., 2016). Educational attainment had resulted in the reduction of mistimed pregnancies (Blum, Astone, Decker, \& Mouli, 2015 ; Prusty, 2014 ; Relwani et al., 2015). This may be because education increases women's knowledge on where, how and when to access contraceptives. Further, education may also result in increased decision-making autonomy: this weakens the top-down patriarchal imposition of decisions on spending, improved communication and when or what healthcare services to seek. In addition, education demystifies the negative perception towards contraceptives and increase confidence in the use of FP services. Contrary to this, other studies in low income countries among women of reproductive age, suggest that education was negatively associated with unmet need and was not a determinant of mistimed pregnancy (Wulifan et al., 2016). It is reasonable to conclude that motivation for childbirth, limited access to FP services and non-abstinence from sex could account for less influence of education on reducing unmet need.

National surveys in Ghana reported an unmet need rate of $29 \%$ (GSS et al, 2014), $16 \%$ in Nigeria (Aransiola, Akinyemi, \& Fatusi, 2014), and 45\% in Kenya (Beguy, Mumah, \& Gottschalk, 2014). This notwithstanding, other researchers have argued that countries can reduce their unmet need rate by advancing efforts in spousal communication and emphasizing its relevance on mistimed pregnancy (Ali, Mawani, Bano, \& Ali, 2016 ; Thapa, Giri, \& Sharma, 2015). These findings are similar to findings of this study and further supported by Mulatu \& Mekonnen, (2016). Spousal communication enhances understanding between couples and improves decision making on the use of family planning services, thereby reducing unmet need and limiting mistimed pregnancies. Contrary, preliminary investigations among African Americans suggest that most couples lacked communication skills and were more likely to nonverbally communicate about methods such as condoms, leading to increased mistimed pregnancies (Higgins \& Smith, 2016). Though spousal communication and approval of family planning is considered a significant factor in reducing mistimed pregnancies (Ezeanolue et al., 2015), majority of respondents' partners in the current study never approved the use of family planning. This is possible with the reason that traditional, cultural and religious limitations could influence partner decisions on approving family planning. However, this did not determine the unmet need of respondents, contrary to studies in Ethiopia where non-partner approval of contraceptive use still led to reduction in unmet need (Arega et al., 2016). In the current study, reasons such as lack of autonomy in decision making to spend self-earnings, education and interest in birth spacing could determine the unmet need of respondents of this study. 
Previous studies have cited working status and place of residence as significant determinants of a woman's unmet need (Begum, Nair, Donta, \& Prakasam, 2014), contrary to findings of this study. Considering that work status and place of residence are potential access barriers to family planning services, it is possible for these factors to determine the mistimed pregnancy rate of respondents. Consequently, the study reported a high unmet need rate with low mistimed pregnancy $(9.4 \%)$. This is contrary to findings by Kennedy et al., (2013) who reported that more than half of child birth were due to mistimed pregnancies. Similarly, mistimed pregnancy varies in different African countries and previous research have reported 26\% in Kenya (Beguy et al., 2014), 28\% in Ethiopia (Dibaba, Fantahun, \& Hindin, 2013), and 10\% in Nigeria (Monjok, Smesny, Ekabua, \& Essien, 2010). In the current study, autonomy to spend own earning (49\%) significantly influenced unmet need, similar to findings of Osamor \& Grady, (2016), which reported that $38 \%$ of women were autonomous in taking decisions on how to spend their own earnings. Women's autonomy as a significant factor in determining unmet need and mistimed pregnancy has been widely observed (Najafi-sharjabad, Zainiyah, Yahya, Rahman, \& Hanafiah, 2013 ; Najafi-sharjabad et al., 2013 ; GSS et al., 2009 ; GSS et al., 2015). This is because when women are empowered on decision-making, their desire to direct resources into healthcare and family planning decisions also increases (Beguy et al., 2014).

\section{Conclusions}

Even though majority of couples had positive perception towards family planning, less than half of the couples communicate on family planning. Most women do not have their partner's approval to use family planning and women who use family planning methods, mostly have access to services from a trained health professional. Evidence from this study indicates that though efforts on dealing with unmet needs are continuously made, there is still a significant drop in the use of family planning services. It is relatively important to shift focus from facility based family planning services to community based service provision and partner education.

\section{Abbreviations}

FP Family Planning

ATR African Traditional Religion

AOR Adjusted Odds Ratio

Cl Confidence Interval

Ref Reference

GSS Ghana Statistical Service

\section{Declarations}




\section{Ethical and consent issues}

The ethical clearance for this study was granted by the ethical review board of Research Web Africa and University of Ghana review board. Written informed consent was obtained from all participants after the study protocol was explained to them. Voluntary participation of participants was assured and no benefits were given to participants who took part in the study. Both signature and thumbprint acceptance of consent was granted by the Ethics Review Board and participants were invited orally to consent and participate in the study. Face to face interviews were conducted and researchers ensured privacy and confidentiality during interviewing process.

\section{Consent to publish}

Not applicable

\section{Availability of data}

Authors are unable to share data publicly because of ethical restrictions

\section{Competing interest}

Authors have no competing interest.

\section{Sources of funding}

No external funding was received for this research.

\section{Authors' contribution}

EJD conceived the study idea and discussed with FDD. EJD, EY and LB supervised the implementation of the study. EJD and FDD analysed the data and wrote the draft manuscript. All authors read, commented and approved the final manuscript.

\section{Acknowledgement}

The authors will like to thank all women in the Sandema district who participated in this study as well as Research Web Africa and the Catholic University of Ghana for granting the ethical clearance to conduct this study.

\section{Author information/details}

EJD holds a Master of Public Health (MPH) degree from the University of Ghana and is currently a graduate researcher at the same University. FDD holds an MPhil in Community Health and Development (MCHAD) from the University for Development Studies and is currently a Ph.D. student at the University of Heidelberg, Germany. EY holds a Ph.D in Population and Health; he is currently a lecturer at the University 
for Development Studies. LB holds an MPhil in Community Health and Development from the University for Development Studies and is currently a tutor at the Nandom Nurses and Midwifery Training College.

\section{References}

1. Adhikari R, Soonthorndhada K, Prasartkul P. Correlates of unintended pregnancy among currently pregnant married women in Nepal. BMC Internatioal Heal Hum Rights. 2009;9(17):1-10.

2. Tebekaw Y, Aemro B, Teller C. Prevalence and determinants of unintended childbirth in Ethiopia. BMC Pregancy Childbirth. 2014;14(326):1-9.

3. Arega M, Surender R p, Ali Y. Prevalence And Associated Factors of Unintended Pregnancy In Dessie City Administration, East Amhara, Ethiopia - Dec ., 2014. Indian J Res. 2016;5(April):27-30.

4. Fotso JC, Izugbara C, Saliku T, Ochako R. Unintended pregnancy and subsequent use of modern contraceptive among slum and non-slum women in Nairobi , Kenya. BMC Pregnancy Childbirth. 2014;14(224).

5. Relwani NR, Saoji A V, Kulkarni M, Kasturwar N, Zade R, Wadke R. Revealing unmet need for contraception among married women in an urban slum of Nagpur. Int J Med Sci Public Heal. 2015;4(8):2-6.

6. Akanksha J, Nandkeshav R, Kalpana K, Vijay D, Mohan D. Unmet Need for Family Planning Among the Married Women of Reproductive Age Group in a Rural Area. Int J Heal Sci Res. 2014;4(November):62-9.

7. Letamo G, Navaneetham K. Levels, trends and reasons for unmet need for family planning among married women in Botswana: a cross-sectional study. BMJ Open. 2015;5(e006603):1-12.

8. Wulifan JK, Brenner S, Jahn A, Allegri M De. A scoping review on determinants of unmet need for family planning among women of reproductive age in low and middle income countries. BMC Womens Health [Internet]. 2016;16(2). Available from: http://dx.doi.org/10.1186/s12905-015-0281-3

9. Mekonnen W, Worku A. Determinants of low family planning use and high unmet need in Butajira District, South Central Ethiopia. Reprod Health. 2011;8(37):1-8.

10. Ayuningtyas D. Unmet need for family planning in Indonesia and the policy strategy of intervention in several countries. Interrnational J Reprod Contraception, Obstet Gynecol. 2016;5(6):1680-5.

11. Hameed W, Azmat SK, Bilgrami M, Ishaqe M. Determining the factors associated with Unmet need for family planning: a cross-sectional survey in 49 districts of Pakistan. Pakistan J Public Heal. 2011;1(1):21-7.

12. Paschal AA, Matthew AA. Factors influencing the uptake of family planning services in the Talensi District, Ghana. Pan Afr Med J. 2015;20(1937-8688):1-9.

13. Ghana Statistical Service. Ghana Demographic and Health Survey [Internet]. Accra: Ghana Statistical Service; 2015. 506 p. Available from: http://dhsprogram.com/pubs/pdf/FR307/FR307.pdf

14. Eliason S, Baiden F, Yankey BA, Asare KA. Determinants of unintended pregnancies in rural Ghana. BMC Pregancy Childbirth. 2014;14(261):1-9. 
15. Pasha O, Goudar SS, Patel A, Garces A, Esamai F, Chomba E, et al. Postpartum contraceptive use and unmet need for family planning in five low-income countries. Reprod Heal. 2015;12(Suppl 2):1-7.

16. Hindin MJ, Rodriguez MI, Gonsalves L, Say L. Adolescent health experience after abortion or delivery ( AHEAD ) trial: formative protocol for intervention development to prevent rapid, repeat pregnancy. Reprod Health [Internet]. 2015;12(111):1-6. Available from: http://dx.doi.org/10.1186/s12978-0150098-4

17. Chebet JJ, Mcmahon SA, Greenspan JA, Mosha IH, Callaghan-koru JA, Killewo J, et al. " Every method seems to have its problems " - Perspectives on side effects of hormonal contraceptives in Morogoro Region, Tanzania. BMC Womens Health [Internet]. 2015;15(97):1-12. Available from: http://dx.doi.org/10.1186/s12905-015-0255-5

18. Ajong AB, Njotang PN, Yakum MN, Essi MJ, Essiben F, Eko FE, et al. Determinants of unmet need for family planning among women in Urban Cameroon: a cross sectional survey in the Biyem-Assi Health District, Yaoundé. BMC Womens Health [Internet]. 2016;1-8. Available from: http://dx.doi.org/10.1186/s12905-016-0283-9

19. Ibrahim Al, Iwaoeye G. Outcome of teenage pregnancy in the Niger Delta of Nigeria. Ethiop J Health Sci. 2012;22(1).

20. Blum RW, Astone NM, Decker MR, Mouli C. A conceptual framework for early adolescence: a platform for research. Int J Adolesc Med Heal. 2015;26(3):321-31.

21. Prusty RK. Use of Contraceptives and Unmet Need for Family Planning among Tribal Women in India and Selected Hilly States. Int J Heal Popul Nutr. 2014;32(2):342-55.

22. Ghana Statistical Service (GSS). Demographic and Health Survey. 2014.

23. Aransiola JO, Akinyemi Al, Fatusi AO. Women 's perceptions and reflections of male partners and couple dynamics in family planning adoption in selected urban slums in Nigeria: a qualitative exploration. BMC Public Health. 2014;14(869).

24. Beguy D, Mumah J, Gottschalk L. Unintended Pregnancies among Young Women Living in Urban Slums: Evidence from a Prospective Study in Nairobi City , Kenya. PLoS One. 2014;9(7):1-10.

25. Ali SA, Mawani M, Bano G, Ali SA. Reproductive System \& Sexual Disorders: Current Research Important Strategies for Effective Family Planning Counseling. Reprod Syst Sex Disord. 2016;5(3):1000184.

26. Thapa N, Giri N, Sharma I. Male Involvement in Contraceptive Use among Tharu People Residing In Dang District of Nepal. Int J Heal Sci Res. 2015;5(September):472-7.

27. Mulatu K, Mekonnen W. Men 's Involvement in Long Acting and Permanent Contraceptive Use in Mizan-Aman District Southwestern Ethiopia: A Community Based Cross-Sectional Study. Heal Sci J. 2016;10(2:2):1-9.

28. Higgins JA, Smith NK. The Sexual Acceptability of Contraception: Reviewing the Literature and Building a New Concept. J Sex Res [Internet]. 2016;53(4-5):417-56. Available from: http://dx.doi.org/10.1080/00224499.2015.1134425 
29. Ezeanolue EE, Iwelunmor J, Asaolu I, Obiefune MC, Ezeanolue CO, Osuji A, et al. Impact of male partner 's awareness and support for contraceptives on female intent to use contraceptives in southeast Nigeria. BMC Public Health [Internet]. 2015;15(879):1-6. Available from: http://dx.doi.org/10.1186/s12889-015-2216-1

30. Begum S, Nair S, Donta B, Prakasam CP. Prevalence of unmet need for contraception in urban slum communities, Mumbai. Int J Reprod Contraception, Obstet Gynecol. 2014;3(3):627-30.

31. Kennedy EC, Mackesy-buckley S, Subramaniam S, Demmke A, Latu R, Robertson AS, et al. The case for investing in family planning in the Pacific: costs and benefits of reducing unmet need for contraception in Vanuatu and the Solomon Islands. Reprod Heal. 2013;10(30).

32. Dibaba Y, Fantahun M, Hindin MJ. The association of unwanted pregnancy and social support with depressive symptoms in pregnancy: evidence from rural Southwestern Ethiopia. BMC Pregnancy Childbirth. 2013;13(135):1-8.

33. Monjok E, Smesny A, Ekabua JE, Essien EJ. Contraceptive practices in Nigeria: Literature review and recommendation for future policy decisions. J Contracept. 2010;9-22.

34. Osamor PE, Grady C. Women 's autonomy in health care decision- making in developing countries: a synthesis of the literature. Int J Womens Health. 2016;191-202.

35. Najafi-sharjabad F, Zainiyah S, Yahya S, Rahman HA, Hanafiah M. Barriers of Modern Contraceptive Practices among Asian Women: A Mini Literature Review. Glob J Heal Sci. 2013;5(5):181-92.

36. Ghana Statistical Service. Ghana Demographic and Health Survey. Ghana; 2009. 512 p.

37. Ghana Statistical Service (GSS), Ghana Health Service (GHS), ICF Macro. Ghana Demographic and Health Survey 2014. Rockville, Maryland, US; 2015. 